\section{DISCURSOS SUBVERSIVOS EN EL CINE NO HABLADO}

\author{
M. ${ }^{a}$ del Carmen Rodríguez Fernández \\ Universidad de Oviedo \\ maica@uniovi.es
}

\begin{abstract}
RESUMEN: "Discursos subversivos en el cine no hablado" se propone analizar las transgresiones de género que aparecen en algunas películas del cine mudo. Por sus caracteristicas al tratarse de un cine no hablado, lo que sugieren algunas imágenes es fundamental para entender los significados de las películas. Las directoras de aquella época eran conocedoras de la importancia de las imágenes y del poder que les confería la cámara para expresar sus reivindicaciones al público espectador. El campo de la cinematografía era nuevo, pero tenía género y las directoras sabian que sus películas eran el vehículo para dar a conocer su articulación como feministas. Le matelas alcoolique, La souriante Mme. Beudet y Dora Films of America Shorts son ejemplos de este privilegio puesto que, aunque las películas de esta muestra pertenezcan a dos etapas del cine mudo y de que sus propósitos fueran diferentes, las directoras y las películas seleccionadas son ejemplos merecedores de una revisión con perspectiva de género.
\end{abstract}

PALABRAS CLAVE: Cine no hablado, discurso, subversión, género, poder, censura.

La etapa del popularmente conocido como cine mudo (1895-1927) constituye un amplio período de más de treinta años en los que, por una parte los cinematógrafos, por otra las historias narradas y también los intereses que movian a todos los que hacían posible aquella industria, avanzaban en su evolución de manera incesante hasta llegar a ser el gran entramado comercial en el que se convertiría en los años veinte y treinta con la presencia del cine sonoro en todas las salas cinematográficas.

A lo largo de esos treinta y dos años de cine no hablado, aquellas primeras imágenes en movimiento, filmadas durante un minuto o minuto y medio, dieron paso a otras que excedian a las primeras por su extensión y eran muy superiores por la aplicación del sonido sincrónico, por la inclusión del coloreado, por la diferente utilización de cámaras pero, sobre todo, porque narraban historias que se iban haciendo más complejas según la cinematografía ad-

\section{SUBVERSIVE DISCOURSES IN SILENT FILMS}

\begin{abstract}
Subversive discourses in silent films" aims to analyse the gender transgression that emerges in certain movies of the silent period. These being silent films, their meaning can only be understood from the content of the images. Directors of the silent period were aware of the importance of images and of their power to put across their views to spectators. The field of filmmaking was new but it was not ungendered, and women filmmakers knew that their films were the vehicle to make spectators aware of their feminist positions. Le matelas alcoolique, La souriante Mme. Beudet and Dora Films of America Shorts are examples of this privilege since, although they belong to two periods of silent film history and have different aims, the directors and the films selected are good examples to be revisited with a gender perspective.
\end{abstract}

KEY WORDS: Silent film, discourse, subversion, gender, power, censorship.

quiría mayor destreza técnica. Los textos fílmicos iban evolucionando hacia argumentos de mayor dificultad, ofrecian diferentes puntos de vista, trataban de mostrar situaciones paralelas espaciotemporales $e_{\text {, }}$ igual que en el relato literario, había también un componente de telling, gestual en este caso, y suggesting muy importante que estimulaba la imaginación del público espectador según la perspectiva que se adoptara y el género en el que se enmarcara la película. Estos dos conceptos telling y suggesting van a ser de gran importancia en el cine mudo pues, al carecer de diálogos y contar únicamente con el elemento gestual y las parcas líneas que acompañaban a algunos fotogramas, lo que las imágenes dijeran o sugirieran abierta o veladamente era el principio fundamental para comprender los significados de los filmes.

El mapa de directoras del cine no hablado está repleto de cineastas a ambos lados del Atlántico y sus nombres 
aparecen recogidos de manera oficial en los catálogos de las filmotecas institucionales y en las colecciones de particulares; sin embargo la cartografía está en muchos casos incompleta porque los testimonios filmicos son escasos. Esto se debe a varios factores: en primer lugar, al hecho de que durante los primeros años, en el período del cine primitivo (1895-1908), el interés de sus creadores estuviera más centrado en el perfeccionamiento de los elementos tecnológicos que en la propia autoría de las obras. Así, aparecen títulos de películas adjudicados a varias personas y en distintas fechas, pues era habitual que los directores asistieran a las proyecciones de sus colegas y que, a partir de ahi, tomaran prestada la historia para proseguir avanzando en la tecnología del reciente invento, sin preocuparse, el autor original de la cinta, de asegurar la autoría intelectual de su obra. En segundo lugar, gran parte de la producción filmica de aquellos primeros años se perdió debido a la composición química del material con el que se fabricaban las películas, llegando a ser frecuente que se incendiaran los filmes en el interior de las latas en las que se guardaban. Un tercer factor, también importante, tiene que ver con el abandono en el que quedaron muchas películas, con frecuencia apiladas en almacenes, en espacios húmedos y polvorientos, lo que las deterioró irreparablemente. Estas causas, aquí reseñadas, hacen que la labor arqueológica de búsqueda y posterior investigación se convierta en un trabajo con frecuencia frustrante pues, en ocasiones, solo han quedado las declaraciones escritas que hablan de las intenciones de las directoras de realizar un determinado filme $o$ las críticas en las revistas de cine de la época, pero se carece del material objeto de estudio.

Las directoras de cine, que desde sus comienzos se habían iniciado en esta actividad, eran conocedoras de la importancia de las imágenes y de su poder de transmisión ideológica. De ahí que utilizaran este medio como vehículo para reafirmarse en sus posturas, de mayor 0 menor aserción feminista, y dar a conocer sus universos narrativos desde la posición de poder que les proporcionaban las cámaras cinematográficas. Sus deseos se manifestaban abierta o subrepticiamente; y detrás de la comicidad, la añoranza y el tedio que podian ofrecer las protagonistas de aquellas historias se escondia todo un mundo de deseos insatisfechos, de escapismos, de venganzas y de reivindicaciones que ellas subvertían en sus textos visuales, de acuerdo con los avances que la cinematografía y el devenir del cine como fenómeno social les proporcionaba.

Las obras objeto de análisis para este estudio son: Le matelas alcoolique (Alice Guy Blaché, Francia, 1902), los Dora Films of America Shorts (1925-1930) de la italiana Elvira Notari y su marido Nicola Notari y La souriante Mme. Beudet de la artista vanguardista francesa Germaine Dulac (1923). Ha habido muchas más películas en las que también se advierte el carácter crítico de las directoras, como puede ser el de Lois Weber en Hypocrites (1914), el de la italiana Francesca Bertini en Assunta Spina (1915) o el de la británica Mary Field en Deferred Payment (1929). En muchos de los filmes, el género aparece como tema principal de la narración, y el mérito de estas directoras se encuentra en que han sabido plasmar los imaginarios de sus personajes y proyectarlos a un hipotético público femenino. Cada una de estas obras tiene sus propias caracteristicas y utiliza estrategias especificas para dar a conocer su mensaje, pero todas ellas constituyen una muestra de cómo las cineastas se reafirmaban como profesionales del cine, denunciaban el trato discriminatorio que padecian las mujeres y articulaban sus universos narrativos en un mundo eminentemente masculino.

Tomando como punto de partida la etapa en la que se enmarcan las obras, es importante establecer los parámetros de actuación de las directoras con respecto al momento en el que se exhiben las películas, su país de procedencia, el público a quien va dirigido el filme y el género cinematográfico utilizado. De ese modo se comprenden mejor el porqué de los textos subversivos de estas directoras, sus propósitos y la transgresión de las normas, a uno y a otro lado del Atlántico.

Desde un punto de vista cronológico, el cine no hablado se divide en tres etapas: el cine primitivo (1895-1908), la época de esplendor del cine mudo (1908-1918) y la etapa en la que el cine se convierte en una industria con un gran entramado empresarial (1918-1927). Entre las dos primeras etapas hay un período intermedio, llamado cine de transición (1902-1908) porque marca el paso del cine de atracción al cine narrativo. Está basado aquél en el vodevil y los espectáculos de magia, con una extensión de uno o dos minutos, mientras que el cine narrativo tiene ya una duración ligeramente superior, lo que permite la narración de una historia, por breve que sea, con un comienzo, 
desarrollo y desenlace. A este momento, corresponde la película de Guy Blaché Le matelas alcoolique.

Los años de esplendor se caracterizan por una amplísima presencia femenina en todos los niveles de actuación: productoras, directoras, guionistas, actrices, fotógrafas, editoras, sastras, peluqueras, maquilladoras, acomodadoras y taquilleras, entre otros oficios. Sin embargo, a este periodo de altísima participación le sigue, en los años veinte, una etapa en la que las mujeres pierden su parcela de poder en la industria, al masculinizarse los estudios cinematográficos y convertirse en grandes empresas con participación económica de Wall Street. Es el momento en el que algunas directoras independientes logran dar a conocer sus obras, sin recibir las presiones comerciales que marcaban los estudios cinematográficos en la década de 1920. De esta última etapa son La souriante Mme. Beudet de la cineasta vanguardista Germaine Dulac y el grupo de películas que la directora italiana Elvira Notari dirigió desde Italia para la colonia de emigrantes italianos en Nueva York.

Otra cuestión de importancia es el interés que tienen los diferentes paises por participar en la carrera tecnológica y artística que va a convertir al cine en un espectáculo de masas sin precedentes en el ámbito cultural. Pues, si bien el cine nace en Francia en 1895 y pocos años más tarde, en 1906, Elvira Notari es ya copropietaria de un estudio y una escuela de arte dramático en Italia, es preciso recordar que en 1896 el americano Thomas Edison también daba a conocer "The Greatest Electrical Novelty in the World", como aparece recogido en el New York Mail and Express. Posteriormente, 1909 marca un hito para el desarrollo de la industria en Estados Unidos, ya que en esa fecha se consiguen unificar los formatos Lumière y Edison porque, aunque ambos tenían el mismo ancho de $35 \mathrm{~mm}$., presentaban unas perforaciones incompatibles. En una conferencia internacional se opta por el formato Edison. Este hecho propicia el desarrollo de la industria y es el desencadenante de que a partir de este momento haya un alquiler y distribución de películas a gran escala, lo que va a tener unas consecuencias comerciales sin parangón.

Por su parte, los nickelodeons, que llevaban funcionando desde comienzos de siglo, adquirieron tal importancia en estos primeros años en los que la industria emergía con fuerza, que las autoridades locales tuvieron que interve- nir en alguna ocasión ante el temor de que las películas pudieran influir en las mentes de los espectadores. Esto hizo necesaria la presencia y actuación de los comités de censores, que garantizarian el contenido moral de los filmes. Como dice Ward Mahar en Women Filmmakers in Early Hollywood:

Nickelodeons, claimed some, were dirty little firetraps, strewn with peanut shells, rocked by noisy crowds and steamy with the effluvium of the urban masses. Within them, "impressionable" audiences of children and immigrants were exposed to deleterious scenes of violence and crime, young men and women exchanged improprieties, and neighbourhood pockets of working-class solidarity flourished. (Ward Mahar, 2006, 78)

La vispera de Navidad de 1908 el alcalde de Nueva York mandó cerrar 550 nickelodeons por razones de seguridad. Ya existía una policía de censura en Chicago y, a la vista de los recientes hechos, para evitar que llegara a ocurrir lo mismo en otras ciudades, los productores y exhibidores se unieron y crearon sus propios comités de censores con el fin de garantizar la moral de las películas y la respetabilidad del cine. En el punto de mira de la censura estaban los filmes que describian crimenes y violencia, aunque también mostraban los censores su preocupación por las cintas en las que abundaba el humor grosero ante el temor de que todo ello pudiera dar lugar a una situación descontrolada, dado el gran número de inmigrantes que llegaban a Estados Unidos y a los movimientos migratorios hacia las grandes urbes. Se pensaba que estos grupos, en los que también se incluía a las mujeres y a los niños, eran fácilmente influenciables.

Las películas que se importaban de Francia eran criticadas con frecuencia, y no eran del gusto de los americanos de clase media por el tratamiento que se daba a la infidelidad marital, por los peligros que concernian a los niños o por sus extravagantes gustos gastronómicos. Con el cierre de los nickelodeons en Nueva York, y con el fin de evitar una intervención a nivel político, la prensa cinematográfica empezó a desarrollar una lista de temas que deberían cuidarse. Quedaba prohibido el sexo, la criminalidad, la violencia y cualquier otra escena que degradara el espíritu religioso.

Las directoras de Le matelas alcoolique, La souriante Mme. Beudet y Dora Films of America Shorts transgreden estas 
prohibiciones y presentan subversiones de género o políticas. El primero de estos filmes presenta el tema de la infidelidad marital jocosamente mediante un lenguaje gestual simbólico. En cuanto a los filmes de Dulac y Notari, se trata de obras realizadas en la década de 1920. La souriante Mme. Beudet es una película independiente que aborda la violencia en la vida de pareja y, por tanto, no encontró los impedimentos que existían para el cine comercial. El conjunto de Dora Films of America Shorts no halló inconveniente para su exportación y exhibición en Estados Unidos, ya que en este caso el obstáculo estaba en su propio país, pero Notari supo burlar la férrea censura política que existía en Italia en aquellos años.

Le matelas alcoolique (fechada en 1906), de la que el British Film Institute (BFI) conserva solo un fragmento', constituye un documento importante del modo en que Alice Guy Blaché presenta a la mujer como sujeto deseante, valiéndose para ello de una situación de pareja en la que prevalece la comicidad. Atendiendo a la contextualización de la película, la cinta se enmarca en la etapa de cine de transición y la copia de The George Eastman House en Nueva York es ya una narración con su inicio, desarrollo y desenlace. En el fragmento consultado en el BFl, la película tiene una duración más corta, de dos minutos, y narra el momento en el que un matrimonio se va a dormir y solicita un nuevo colchón a su casera. Ésta les trae un colchón nuevo, recién vareado, pero cuando el matrimonio se desnuda y se mete en la cama, la pareja se da cuenta de que el colchón se mueve porque hay un hombre metido dentro. En la versión americana consultada por McMahan, una mujer casada sale a la calle a varear su colchón. En un momento determinado abandona su tarea para atender otros compromisos, instante que aprovecha un borracho para acostarse a dormir. La mujer regresa a su labor y cose el colchón, una vez aireada la lana, sin percatarse de que hay un hombre dormido en su interior. Cuando el marido regresa a casa, ambos colocan el colchón en la cama y al irse a acostar el colchón comienza a moverse y el matrimonio descubre finalmente al intruso.

La película es interesante desde una perspectiva de género porque permite una lectura que excede el aspecto cómico de la situación, referida esta vez a la monotonía de la rutina diaria de un matrimonio y a la necesidad de "airear" o dar nueva vida a la relación de pareja e incluso a las demandas de mayor actividad sexual por parte de la mujer. Evidentemente, el fragmento del BFI no permite todas estas apreciaciones porque faltarian elementos importantes, como serían: la salida del espacio privado al público para "airear la lana", el que la mujer "desatienda" el colchón, base de su vida en pareja, para atender a otras ocupaciones y el hecho de que un extraño, un borracho desinhibido, se aloje en su interior. Detrás de esta situación de hilaridad hay connotaciones de deseos reprimidos de la pareja en su ámbito doméstico, e irreprimidos, encarnados en el personaje del borracho, que simbolizan los deseos sexuales irrefrenables de lo que se considera un comportamiento inapropiado.

En este marco la mujer es la protagonista, el borracho es el antagonista y el marido es el tercer personaje. La esposa es quien actúa, la que lleva el peso de la acción al salir a la calle para airear la lana y ocuparse de distintos quehaceres domésticos dentro y fuera del domicilio. El climax de la historia tiene lugar cuando la pareja se acuesta sobre el colchón, epítome de su vida marital y de sus deseos sexuales. En este punto, los movimientos que surgen del interior del colchón explican las demandas de mayor atención sexual por parte del personaje femenino. El desenlace lo constituye el descubrimiento de que hay otro hombre "en la cama". Así pues, por su temática, según los códigos morales que se establecerian cinco años más tarde, la película se encuadraría en la comedia ligera extranjera al tratar el tema del simbólico adulterio de una manera alegre. A pesar de su brevedad, el filme dice mucho de la posición articulada y feminista de Guy Blaché, ya que, como dice McMahan:

Aunque el personaje es interpretado por un hombre vestido de mujer, de acuerdo con la práctica habitual en la industria cuando era necesario rodar escenas peligrosas, la fuente del humor es la misma: una mujer debe pedir ayuda a media docena de hombres en distintos lugares públicos mientras lucha a brazo partido con el símbolo desbocado de su deseo y la domesticidad matrimonial. (McMahan, 2002, 152)

El fragmento que se conserva en BFI, aunque incompleto, deja al descubierto el hecho de que en aquella etapa primitiva había permisividad en las escenas que narraban las relaciones de pareja, a la vez que muestra la capacidad del público para actuar como voyeur. Dentro de la fase de transición, este filme se encuadra en el subtipo de modelo erótico. Según Richard Abel, este modelo conlleva secuen- 
cias voyeurísticas, que en su mayoría interponen el acto de mirar por el ojo de una cerradura o atisbar por el resquicio de una puerta, entre otros recursos. Para McMahan, en las películas de Alice Guy Blaché no aparece el voyeur como mediador entre el público y el propio espectáculo (McMahan, 2002, 167), lo que implica, en mi opinión, un avance en su técnica, al conceder a los espectadores la capacidad de convertirse en voyeurs implícitos en la oscuridad de la sala cuando se trata de escenas con una significación erótica no perceptible en una primera visualización.

Laura Mulvey explicaria algunas décadas más tarde en Visual and other Narratives que una de las miradas que con más fuerza se ejercen sobre una película es la que tiene al público espectador como su portador en la sala de cine. En este espacio, merced a la oscuridad, aun tratándose de un ámbito público, los espectadores se sienten como si estuvieran disfrutando del placer de mirar individualmente, lo que les convierte en voyeurs. Tomando como referencia, de nuevo, a McMahan, quien dice que no hay en las películas de Guy Blaché un elemento mediador que permita al espectador ejercer de mirón y atisbar lo que ocurre en la estancia y, de nuevo, con el privilegio de saber que unos años más tarde este tipo de escenas estarian prohibidas, se puede afirmar que el público está actuando como voyeur. La naturalidad de ésta y otras escenas similares se perdería en el transcurso de los años, especialmente en los años treinta, en pleno auge del cine clásico de Hollywood con la publicación y puesta en marcha del Código de Censura Hays que prohibiría, entre otras muchas, las escenas en las que un matrimonio apareciera compartiendo el lecho matrimonial o aquellas en las que mostraran desvistiéndose, como ocurre en Le Matelas alcoolique, en el fragmento del BFI.

La souriante Mme. Beudet es otro ejemplo de película que difícilmente hubiera superado la censura moral si no se tratara de una obra realizada por una directora independiente. Germaine Dulac, directora francesa perteneciente a las vanguardias, desarrolló su obra artística en la década de 1920, época en la que la gran industria cinematográfica buscaba solo el beneficio económico; sin embargo, mantenerse al margen del cine comercial le permitió hacer un cine alternativo y convertirse en una autora, como a ella le gustaba definirse. Películas como La souriante Mme. Beudet y Âme d'artiste son algunas de sus muchas creaciones. Fue una figura de relevancia en el movimiento impre- sionista e integrante de la llamada "segunda vanguardia francesa", contribuyendo a la misma con La coquille et le clergyman (1927), filme importantísimo para los surrealistas e inspirado en la obra de Antonin Artaud. Su trayectoria profesional como crítica, promotora del movimiento de cineclubs en Francia, auteur cinematográfica, conferenciante y autora de infinidad de reseñas y ensayos críticos la convierte en la directora con la carrera profesional más completa del período del cine mudo a nivel mundial.

La souriante Mme. Beudet está considerada por la crítica como el primer filme feminista de la historia y supone un avance de lo que unos años más tarde iba a ser el cine surrealista. En el filme se presenta la aburrida vida provinciana de una mujer casada con un comerciante. La acción transcurre en dos días y tiene como escenario la sala y el dormitorio del matrimonio. La película está basada casi por completo en las fantasías de Mme. Beudet, que intenta huir así de un matrimonio tedioso. La protagonista pasa el tiempo tocando el piano, leyendo un libro u hojeando una revista y fantaseando con la idea de golpear e incluso matar a su marido. Cualquier imagen despierta en su imaginación el deseo de violencia, alimentado sobre todo por la insistencia de aquel por bromear continuamente con una pistola descargada que se coloca en la sien simulando su suicidio. El primer día, de los dos en los que se desarrolla la acción, la pareja recibe una invitación para ir a la ópera con un matrimonio amigo, la esposa rechaza la invitación, se queda sola en casa y aprovecha la ocasión para cargar el arma, lo que deja entrever la intención homicida de la esposa, quien desea que el suicidio del marido, tantas veces anunciado con sus bromas, finalmente se lleve a cabo. Mme. Beudet pasa muy mala noche a consecuencia de las pesadillas que padece por la acción que está dispuesta a cometer; a la mañana siguiente se levanta con la intención de descargar el arma, pero ya no hay tiempo. El marido juguetea con la pistola que guarda en el cajón de su escritorio, ésta se le dispara y hiere a la esposa levemente. Monsieur Beudet cree que ella ha contemplado la idea del suicidio durante su ausencia y la película finaliza con la supuesta redención de la protagonista, o al menos eso cree el marido, que la toma del brazo para llevársela de paseo. La escena final muestra a la pareja saliendo de la casa, caminando de espaldas a la cámara y aparentando ser un matrimonio feliz.

En La souriante Mme. Beudet, Dulac se posiciona del lado de la protagonista al crear un personaje subversivo que, 
siquiera en su fantasía, imagina diferentes tipos de castigo para el marido ante la imposibilidad de hallar una salida a la deteriorada convivencia de su vida marital. Su existencia la conforman la música al piano y la lectura. La directora dirige la atención del público a tres objetos que están en la sala: por una parte, un almanaque en el que se ve la fecha 30 de abril, que en diversas ocasiones llama la atención de los espectadores por su focalización e iluminación. La importancia que da Dulac a este objeto puede interpretarse como el insoportable paso de los días para Mme. Beudet, pues al fijarnos en el almanaque se crea una empatía con este personaje, tan torturado psicológicamente; pero también puede tratarse de un guiño al público espectador por parte de Dulac, para hacerle partícipe de cuál es el propósito de su cine y cómo, sin apenas acción, se puede lograr un filme en el que el poder de sugerencia de las imágenes es más importante que la narración en sí. Los espectadores pueden asociar la reiterada presencia del almanaque con la importancia que adquiere el tiempo como recurso fílmico para mostrar de manera artística el mundo interior de la protagonista, pues Dulac alarga las escenas más de lo que era habitual en el cine comercial, contribuyendo con ello a mantener la atención sobre los personajes, sus conflictos internos, así como los elementos que los rodean.

El segundo objeto sobre el que se centra la atención de manera especiales un florero que está colocado encima de una mesa que ocupa una posición central en el campo filmico. Ambos protagonistas lo mueven continuamente de sitio: él lo sitúa en el centro y ella lo pone a un lado de la mesa. Los reiterados cambios del margen al centro y viceversa pueden entenderse como sus diferentes puntos de vista y su disensión en la vida diaria, en la que, al no haber entendimiento y complicidad en su relación de pareja, el lenguaje de los movimientos y de los gestos adquiere gran importancia. Para él, el centro puede ser sinónimo del orden preestablecido que quiere mantener a toda costa; para ella, su interés por situarlo a un lado de la mesa implica el deseo de cambiar ese orden y hacer valer su opinión, hasta ahora marginada y no tenida en cuenta.

El tercer objeto referencial es una muñeca con el cuerpo de trapo y la cabeza de porcelana que descansa sobre el piano de Mme. Beudet. Su marido, enfadado porque no encuentra unas facturas que desea revisar con su socio, coge la muñeca de manera brusca y la rompe, separándole la cabeza del cuerpo. Sin saber qué hacer con ella, primero se la guarda en un bolsillo y después vuelve a colocarla sobre su cuerpo inerte. De nuevo, esto se puede interpretar como la inanición de la protagonista y también como el deseo de violencia que aflora momentos antes del desenlace del filme. Ambos objetos, el florero y la muñeca, evocan la idea de vida-objeto en la que está sumida la mujer, sin capacidad de acción, ya que ambos adornos solo sirven para ser contemplados.

Tan interesante o más que el tema feminista es el logro artístico de Dulac al hacer de esta película una obra en la que el pensamiento adquiere una nueva expresión, la del deseo violento que domina las fantasías de Mme. Beudet. Para las críticas feministas Petrolle y Wexman "women who direct experimental films respond to a patriarcal context fraught with voices and images that describe the world from a masculinist perspective" (Petrolle y Wexman, 2005 , 1). A pesar de que en la historia apenas hay acción, si existe, en cambio, mucha violencia por parte de ambos personajes. Como dice Maureen Turim en "The Violence of Desire in Avant-Garde Films": "Something in the way surrealism imaged the violence mysteriously underlying desire discloses more than we see at first in the ordered narratives of various genres of realism" (Turim, 2005, 71). Todas las fantasias del personaje tienen como propósito dar muerte al cónyuge: un ejemplo lo tenemos en la fotografía del tenista que Mme. Beudet ve en la revista y que, en su imaginación, se convierte en el hombre capaz de matar al marido de un raquetazo; otro modo de ilustrar esta violencia aparece cuando Mme. Beudet queda sola en la casa y carga el arma para que él, en una de sus reiteradas bromas, se la dispare sobre la sien. Para Turim: "Dulac focuses on Mme. Beudet's subjective memories of her husband's behaviour. Images rendering his boorish games and belittling offensive displays penetrate her solitude. The evolution of her reaction into a violent revenge fantasy relieves her boredom and passivity" (Turim, 2005, 74). Por su parte, el marido también hace uso de esta violencia encubierta cuando coge con rabia la muñeca y se queda con su cabeza en las manos o cuando simula que va a disparar a su mujer, lo que efectivamente ocurre porque el arma está cargada.

El modo en el que Dulac explora el perfil psicológico de los personajes, la iluminación del rostro de la protagonista, la ralentización de las escenas cuando se toman primeros planos de su cara o de sus manos, la utilización del efecto 
flou con su falta de nitidez, el desenfoque intencionado, al igual que la sobreimpresión, son técnicas cinematográficas con las que ella trabajó en su vida profesional, motivada por una constante experimentación. Dulac es una directora comprometida con las ideas feministas. Mme. Beudet es también un sujeto deseante que no duda en llevar a cabo su acción homicida, pero, a su vez, esta directora es consciente de la situación de inferioridad y subordinación en la construcción de género, de ahí que el final de la historia muestre a una esposa de espaldas a la cámara, que camina junto a su marido, siguiendo los designios que la sociedad destinaba a las mujeres.

Un ejemplo totalmente diferente es el de los Dora Films of America Shorts (1925-1930), pues no se conservan estos textos visuales. Sin embargo, es importante su inclusión como discursos subversivos porque existe abundante documentación escrita sobre las circunstancias personales y políticas que rodearon a Elvira Notari y cómo transgredió las normas para enviar el material fílmico a América.

A Elvira Coda Notari (1875-1946), primera directora del cine italiano, se la considera la directora de las calles de Nápoles, porque en su obra cinematográfica describía a las gentes napolitanas y su acontecer en la vida diaria de los comienzos del siglo XX. Los escasos documentos filmográficos que se conservan y las referencias que sobre su obra hacen las revistas especializadas de la época constituyen los fundamentos para llevar a cabo la labor arqueológica de reconstrucción de su importancia como cineasta. Su biofilmógrafa, Giuliana Bruno, realiza un magnífico estudio en Streetwalking on a Ruined Map ${ }^{2}$, cuyo título no puede ser más apropiado para este cometido, pues rescatar y hacer visible a Elvira Notari para la historia del cine implica seguir su pista por las calles napolitanas, ver las localizaciones que la cineasta elegía para sus filmes, recorrer los espacios de Films Dora, su productora, y los lugares donde se exhibian sus películas.

El desprecio con el que la trataron algunos de sus coetáneos anima a revisar su biofilmografía con una perspectiva de género, pues su posicionamiento desde los márgenes abre vías para un análisis desde otras vertientes que no sean las canónicas, tan importantes en la Italia de comienzos del siglo XX: por una parte, su interés por la historia de los pueblos $y$, por otra, la importancia que tuvieron sus películas entre los emigrantes italianos en América.
Sus filmes traspasaron el océano Atlántico y tuvieron mucho éxito en Nueva York en las primeras décadas del pasado siglo; no en vano sus historias, revividas por sus conciudadanos, y especialmente conciudadanas, del otro lado del mar, les alentaban a seguir adelante en la ardua tarea de abrirse camino en el país de las oportunidades, a la vez que les servía de cordón umbilical para no sentir el desarraigo de sus costumbres y de sus gentes.

Elvira Coda Notari está reconocida como la primera directora italiana; aunque el hecho de no figurar en los anales del cine no fue, desgraciadamente, excepcional, pues cuando comenzó a hacerse el rastreo por archivos y filmotecas la mayor parte del legado del cine mudo italiano estaba ya en manos de coleccionistas, en filmotecas fuera de Italia o, si no, irremediablemente deteriorado por la utilización de los componentes químicos de las cintas que, con el paso del tiempo, habian destruido tan preciosa herencia. Una de las investigadoras que primero apreció el valor de la obra de Notari fue la historiadora del cine italiano Mira Liehm, quien dice: "Notari is said to challenge the acceptance of man as supreme judge, offer excellent examples of filmmaking with a unique handling of social themes ...[and] emerge as a director of excepcional talent, confirming theoriginality of the Neapolitan school" (en Bruno, 1993,12).

Gran parte de su obra se perdió por las mismas razones que afectaron a la mayoría de las obras de todos los directores de la época y esta pérdida afectó muy seriamente a la figura de Elvira Notari, doblemente perjudicada: como directora de cine mudo, en general, y por su condición de mujer perteneciente a la llamada escuela de cine napolitana, en particular.

La situación política de Italia y una coyuntura económica favorable a comienzos del siglo XX fueron factores determinantes para la creación y desarrollo de varias escuelas cinematográficas, pues ya en 1896 Italia tuvo conocimiento del gran invento de los hermanos Lumière. Desde ese momento, las personas interesadas en el cinematógrafo comenzaron a hacer sus primeras filmaciones con tanto entusiasmo que en 1905 ya estaba organizada una industria cinematográfica importante. Las escuelas de Roma, Turín, Milán y Nápoles constituyeron la meca del cine del momento. El cine se convertía en el vehículo por excelencia para exhibir y diseminar la importancia y el peso histórico 
de Italia en el mapa político de la época. Pronto vieron las autoridades gubernativas y los cineastas del norte un filón en este nuevo invento que atraía a las masas en sus exhibiciones públicas. El hecho de que Italia como país unificado datase de 1861 contribuyó a crear una conciencia colectiva sobre la necesidad de reforzarse como nación cuyo pasado era necesario connotar para incidir en su empoderamiento nacional. El cine permitía recrear las grandes gestas de su historia y dar a conocer al mundo las glorias de su pasado y su contribución al desarrollo de Europa, lo que les hacía merecedores de ser considerados una parte importante de la cuna de Occidente.

Por otro lado, el sentimiento históricamente arraigado de regionalismo que existía entre los italianos en lo referente a su cultura, sus pueblos, sus gentes y sus dialectos, creó una situación dicotómica, manifestada en dos grandes facciones en su manera de entender el cine: la del norte de Italia, impulsora de una necesaria articulación como país histórico, grandioso y triunfal, y la del sur, amante de preservar su identidad como región, cuyo cine era realista y fácilmente identificable, tanto por sus personajes como por el contenido de sus textos. Es decir, frente al heroismo, el ideal de unidad y el concepto de cohesión nacional del norte se encontraba el cine del sur, mucho más artesanal, que concedía prioridad a los habitantes de los pueblos y a su vida diaria.

La coincidencia de estos sentimientos patrióticos o regionalistas con un momento económico de gran expansión coadyuvó al gran desarrollo que tuvo la industria cinematográfica italiana en aquel momento. La escuela realista del sur de Italia, caracterizada por su regionalismo, no era bien vista por los cineastas y críticos cinematográficos de la industria italiana del norte, quienes despreciaban la labor de Notari no solo por ser napolitana sino por ser mujer. Así, no es extraño encontrarse con comentarios como: "Notari go and pick clams in the harbour of her home-town" (Bruno: 1993, 25), o esta otra referencia a sus películas: "No, no, in the name of God, never should these spectacles be repeated in an elegant theatre, a theatre like this, centrally located and with such a glorious past! No, in the name of the good name and propriety of our national cinema!" 0 como dice Roberto Paolella en Storia del cinema muto (1956): "The most characteristic production is the one of Dora Film, whose destiny was presided over by the whole Notari family: the father, director; the son (Gennariello) protagonist; the mother, the Carolina In- vernizio of the Neapolitan screen, scriptwriter" (en Bruno, 1993 , 28). Se trata de referencias misóginas, de desprecio hacia la directora y su obra, con una alta dosis ideológica de la misión de Occidente como salvadora del mundo. La imprecación a Dios, la referencia a un teatro "elegante", "situado en el centro", "con un pasado glorioso" y la alusión al "cine nacional" dejan patente el pensamiento de aquellos críticos, en consonancia con la ideología fascista que se extendía por Italia a comienzos del siglo XX y que manifiesta cómo se pretendía infravalorar la labor de Notari, bastante diluida ya bajo el manto patriarcal de su familia.

A partir de su matrimonio con Nicola Notari, su nombre iba a pasar a ser el de Elvira Notari y a estar indefectiblemente unido a su marido, en detrimento de su articulación autorial, pues Elvira Notari no figuraría en el futuro como la propietaria ni física ni intelectual de Films Dora. Su nombre quedaría relegado, por detrás del de su marido y del de su hijo, en los créditos de los filmes. Si se ha podido restituir su importancia dentro de la empresa familiar, al lugar que por derecho le corresponde, ha sido, en gran medida, gracias a la labor realizada por su hijo Edoardo, interesado en visibilizar el trabajo desarrollado por su madre, pues como él ha dicho:

Elvira Notari, contrary to what many misinformed historical sources report, directed all films of our production, from the very first to the very last, and thus including also all the features, which were about sixty. Not only this, she was the author of the original scripts and of the scripts adapted from novels or songs ... I worked as an actor in almost all the films ... with the pseudonym "Gennariello". (Edoardo Notari en Bruno, 1993, 92)

En 1909 Elvira y Nicola Notari fundaron su productora Films Dora, que funcionó hasta 1930. La cineasta tiene reconocidas oficialmente sesenta películas de ficción además de sus series tituladas Augurali y Arrivederci (entre 1906 y 1911), brevisimas filmaciones con las que, según se tratara de una serie u otra, se daba la bienvenida a los espectadores, al tiempo que se anunciaba la película que iban a ver, o se les despedía, mientras se expresaba el deseo de volver a verles en el cine. Igualmente figuran en su haber las series Dal Vero, que consistían en filmaciones panorámicas, muy económicas al no necesitar actores 0 actrices profesionales ni un guión previo. También son suyas Actualities and Short Documentaries, filmaciones de acontecimientos reales en las que Elvira trabajaba como 
directora y Nicola como cámara. Tan importantes o más que estas diferentes obras fueron sus Dora Films of America Shorts (entre 1925 y 1930), que componen un total de setecientos filmes sobre la inmigración italiana en Estados Unidos, todos ellos firmados por Elvira y Nicola Notari.

Elvira Notari no fue solo una pionera con una cámara por las calles de Nápoles, fue también la cofundadora y dueña intelectual de Films Dora, empresa que producia y distribuía sus películas, y que poseía incluso su propio canal de distribución en Nueva York. Films Dora tenía a su cargo toda la cadena de producción. En sus estudios se filmaban gran parte de las escenas; las restantes se realizaban en localizaciones de las calles de Nápoles. Disponían de su propio laboratorio, donde se realizaban todas las tareas de revelado, impresión, edición y coloreado manual. Elvira Notari actuaba como un motor dentro de la empresa familiar que funcionaba como un espacio privado extrapolado a la esfera pública. En este nuevo ámbito público pero intrínsecamente doméstico, Notari llevaba todo el peso y la responsabilidad como si de una esposa y madre se tratara dentro de un organigrama familiar histórica y culturalmente arraigado. Su labor era generosa, abnegada e invisible. A pesar de su capacidad de trabajo y de su buen hacer en distintos campos, no pudo enfrentarse a las limitaciones de la sociedad patriarcal italiana, que cercenaba sus posibilidades profesionales en la esfera pública, usurpándole sus derechos de figurar al frente de Films Dora y cuestionando su profesionalidad como directora.

En los primeros años de su carrera, la directora y empresaria Notari no pudo disfrutar plena y abiertamente del espacio que ella había creado, ni sentirlo como propio, puesto que carecía del segundo elemento clave en la articulación de una mujer: su independencia de la economía familiar, lo cual le habría supuesto la emancipación del marido y la propiedad intelectual que lícitamente le correspondía; pero aún hubo más, pues para sus colegas era una invasora, al irrumpir en la esfera pública profesionalmente, ocupando un espacio que ellos creían masculino. Como dice Bruno: "In so far as she was a film pioneer, she was also a kind of immigrant, venturing onto a terrain that had to be conquered and explored onto the borders of a new frontier of language" (Bruno, 1993, 135). Por tanto, se puede afirmar categóricamente que, hasta que se comenzaron a comercializar sus películas en Estados Unidos, fue una mujer en habitación ajena, a la que se le pusieron todo tipo de trabas e impedimentos que reconocieran su valía profesional.
La posición de Elvira Notari siempre alejada del centro, de lo que marcaba el canon, abría vías para un análisis desde otras vertientes: una de ellas, su interés por las pequeñas historias de los pueblos; la otra, la importancia de sus películas entre las emigrantes italianas en Nueva York. Esta marginalidad, deseada o impuesta, iba a ser su gran baza a la hora de transgredir la ideología política. Su elección del sur frente al norte, de preferir a las gentes humildes en vez de a los héroes del pasado, su identificación con los emigrantes y no con la clase media italiana, hizo que ella encontrara su espacio en los cines de América.

Uno de los méritos de Notari es el hecho de haber sido capaz de mostrar unos intereses diferentes a los de sus colegas y de escapar a la férrea censura fascista para poder exhibir sus películas napolitanas en América. Esto la convirtió en una transgresora pasiva al actuar en los límites de la legalidad y subvertir su aparente conformismo y consentimiento dentro de Films Dora en el nuevo mercado para sus películas. La exhibición de éstas en la colonia de emigrantes, que desde el sur de Italia habían emigrado a la gran urbe neoyorquina, le permitió identificarse con las espectadoras italianas que sí habían logrado crear su espacio social y trasladarlo de la piazza al punto de encuentro a la entrada del cine ya la propia sala, donde aquellas mujeres se convertían en sujetos espectatoriales.

Sus películas viajaban al nuevo continente en los barcos que iban repletos de emigrantes italianos. Cuando las películas llegaban a América, Films Dora disponía de un mecanismo de distribución para sus filmes en Nueva York, centro neurálgico de la pequeña Italia emigrada. Dada la altísima presencia de italianos, principalmente del sur, las películas de Elvira Notari tenían una función importantísima para aquellos hombres y mujeres que habían emprendido un viaje sin retorno, pues por medio de aquellas películas, donde se recreaban los lugares, los paisajes y el modo de vida del sur de Italia, los emigrantes italianos (principalmente eran mujeres las consumidoras del producto) mantenían viva en su memoria su identidad como pueblo. A su vez, el cine servía como marco social de punto de encuentro para el conjunto de los emigrantes italianos, en una urbe tan grande donde su presencia quedaba de otro modo diluida entre las numerosas poblaciones de diferentes nacionalidades que llegaban a América a comienzos del siglo XX. Como dice Miriam Hansen: "The movie theater took the place of previous sites of social 
interaction and became a place of public recognition" (en Bruno, 1993, 129).

Tal era el interés de los emigrantes italianos por este tipo de películas, necesarias para preservar su identidad y su memoria colectiva e individualmente, que se constituyó en una industria que se retroalimentaba. Los propios emigrantes, que habían llegado en busca de su "sueño americano," daban el dinero para producir los filmes que los Notari hacian en Italia recorriendo los lugares de donde eran originarios los emigrantes. Como las principales consumidoras del producto eran mujeres, su calidad como sujetos espectatoriales era muy importante. El cine les ofrecía un espacio privado donde rememorar y dar rienda suelta al desarrollo de sus fantasías, lo que les permitía reafirmarse en su identificación como mujeres italianas, con lo que ello implicaba por todo lo que habían dejado atrás y por su desplazamiento a un nuevo espacio todavía por definir, produciendo en el público un sentimiento de satisfacción. En palabras de Hansen:

The cinema provided for women, as it did for immigrants and recently urbanized working class of all sexes and ages, a space apart and a space in between. It was the site for the imaginative negotiation of the gaps between family, school, and workplace, between traditional standards of ... behavior and modern dreams. (En Bruno, 1993, 131)

Teniendo en cuenta la "teoría de la mirada" mulviana, bien se puede afirmar que ese placer por mirar e identificarse con el personaje de la pantalla es también aplicable a las espectadoras italianas de la época del cine mudo que iban a ver las películas de Notari. Es decir, en cuanto que, por su temática, las películas napolitanas trataban de la vida diaria, en la que tenían una alta participación las mujeres, las emigrantes que asistían a los cines se veían reflejadas en los personajes femeninos de la pantalla. Mediante esta identificación, en la que recordaban su pasado reciente a través de las historias napolitanas, sentían placer con el espectáculo que tenían ante sus ojos en el silencio y la oscuridad de la sala, sabedoras de que disfrutaban de un tiempo (la duración de la película y su pasado napolitano) y un espacio propio (la sala de cine y su nostalgia por el devenir diario en su pais natal). Para Judith Mayne, el cine proporcionaba a las inmigrantes un engrandecimiento personal, puesto que se les ofrecía un espacio privado: "[for] women in industrializad society, the public sphere exists primarily as a magnification of the personal ... seated in a movie theatre, the immigrant is offered one kind of private space" (Mayne, 2002, 80-81).

Aquellas mujeres eran conscientes de su privilegio espectatorial, en el que la piazza se había trasladado como espacio social a los aledaños y al interior del cine. A este placer había que añadir el morbo de saber que muchos de los filmes carecian legalmente del permiso de exhibición e intentaban escapar al férreo control fascista, por lo que esa identificación se acentuaba, pues era bastante similar a su posición de extrañamiento, de otredad, tanto en el país dejado atrás, por ser de pueblos del sur y no de las ciudades del norte, como en el de acogida, por ser emigrantes.

Entre Films Dora y el público espectador emigrante se había creado una situación de identidad placentera correlativa a la existente entre Nápoles y Nueva York. Aquellas mujeres italianas habían dejado atrás su país en busca de mejores oportunidades de trabajo y encontraban en el cine la piazza de sus orígenes. Mientras, en Italia, Elvira Notari había encontrado también su sueño americano. Los Dora Films of America Shorts se habian convertido en una fuente de ingresos importante. La empresa sabía cómo burlar a la censura, puesto que todas las películas tenían que ser enviadas a Roma para obtener el permiso de distribución y mientras estaban a la espera de que llegase la autorización legal, los Notari solicitaban un permiso temporal que permitía a sus películas salir hacia América. Muchas veces, cuando la autorización o prohibición de exhibición llegaba, sus películas llevaban varios meses de exhibición al otro lado del Atlántico.

La satisfacción que sentía Elvira Notari no era solo por la buena marcha de la empresa familiar. Se había creado una sobreidentificación o sororidad con las espectadoras napolitanas que asistian a ver sus películas. Ella también, como directora y primer sujeto espectatorial, disfrutaba del placer que sus películas provocaban entre sus hermanas en la pequeña colonia de la urbe neoyorquina. Como dice Bruno, si se supera la construcción de la feminidad como un lugar negativo, el ejemplo de Notari sugiere formasen las que la condición de pérdida de la mujer inmigrante puede ser considerada en términos dinámicos. Este extrañamiento que siente puede entenderse como una ausencia positiva de límites y confinamiento. La nueva condición no necesariamente implica pérdida, sino que puede significar la desaparición de un espacio que le ha sido impuesto a la mujer y una tensión creada por la extensión del límite. 
Elvira Notari habia sido también inmigrante dentro de su pais y conocía muy bien el sentimiento de otredad en el ámbito cinematográfico. Desplazada del lugar que como directora le correspondía al frente de Films Dora y por pertenecer a la escuela napolitana, había logrado su articulación por medio de la diferencia y había encontrado su espacio en ese estadio de autosatisfacción que le proporcionaba la identificación con las espectadoras, en cuanto que como mujeres inmigrantes se encontraban en un exilio habitando el terreno de los otros; había descubierto su lugar en las múltiples posibilidades que el cine ofrecia a tantas mujeres napolitanas que veian sus filmes.
Los tres ejemplos analizados constituyen una muestra de cómo algunas directoras del cine no hablado, sabedoras del poder que tenían con sus cámaras, supieron encontrar la manera de subvertir, por medio de lo que sugerían las imágenes, su escaso margen de maniobrabilidad (en el caso de Elvira Notari) y la intencionalidad implícita de unos sujetos deseantes, en filmes tan distantes en el tiempo y tan dispares en el modo de filmar como puedan ser Le matelas alcoolique o La souriante Mme. Beudet. Unos años más tarde, con la llegada del cine sonoro, las directoras perderían esa parcela de poder tan importante que, salvo en algunos casos muy concretos, no se recuperaría hasta bien entrada la segunda mitad del siglo XX.

\section{NOTAS}

1 Según el estudio de McMahan, existe una copia completa en The George Eastman House en Nueva York.

2 En la elaboración de este apartado he seguido a la profesora Bruno por ser ésta la única fuente de la que se dispone y por tratarse de un estudio riguroso, realizado desde una perspectiva de género.

\section{BIBLIOGRAFÍA}

Abel, Richard (1994): The Ciné Goes to Town. French Cinema (1896-1914), Berkeley, CA, University of California Press.

Bruno, Giuliana (1993): Streetwalking on a Ruined Map,Princeton, Princeton University Press.

McMahan, Alison (2002): Alice Guy Blaché (trad. de Marta Heras), Madrid, Plot Ediciones, 2006.

Mayne, Judith (2002): "Women in the Avant Garde", en Experimental Cinema. The Film Reader, eds. Winston Dixon Wheeler y Gwendolyn Audrey Foster, London \& New York, Routledge, 81-113.
Mulvey, Laura (1989): Visual and Other Pleasures, New York, Palgrave.

Petrolle, Jean \& Wright Wexman, Virginia (2005):Women and Experimental Filmmaking, Illinois, Illinois University Press.

Turim, Maureen (2005): "The Violence of Desire in Avant Garde Films", en Women and Experimental Filmmaking, eds. Jean Petrolle \& Virginia Wright Wexman, Illinois, Illinois University Press, 71-90.

Ward Mahar, Karen (2006): Women Filmmakers in Early Hollywood, Baltimore, The John Hopkins University Press.

\section{FILMOGRAFÍA}

Âme d'artiste (Dir. Germaine Dulac, 1924). Deferred Payment (Dir. Mary Field, 1929).

Dora Films of America Shorts (Dirs. Elvira y Nicola Notari, 1925-1930).

Hypocrites (Dir. Lois Weber, 1914).

La coquille et le clergyman (Dir. Germaine Dulac, 1927).

La souriante Mme. Beudet(Dir. Germaine Dulac, 1923).

Le matelas alcoolique (Dir. Alice Guy Blaché, 1906).
Fecha de admisión: 30 de mayo 